\title{
Photovoltaic hybrid boost converter fed switched reluctance motor drive
}

\author{
Ravi Kiran Dasari, Dharmaraj Godwin Immanuel \\ Department of Electrical and Electronics Engineering, Sathyabama Institute of Science and Technology, Chennai, India
}

\begin{abstract}
Pollution from conventional transportation methods is a worrying factor. Electric vehicles are a viable option to reduce environmental pollution and to replace the conventional methods of using internal combustion (IC) engine based transportation system. renewable source driven electric vehicles (EV) opens up non-dependency on conventional energy sources. The renewable energy source (like photovoltaic system) insists on the switch mode converter to augment its voltage range. This paper presents a hybrid boost switch mode DC-DC converter to increase the voltage range of the photovoltaic (PV) system. The wheels of electric vehicle are coupled to switched reluctance motor (SRM). Closed-loop speed controlled SRM drives the wheels of EV. Asymmetrical converter feeds the excitation current to the coils of $6 / 4$ pole current-controlled SRM. The proposed EV system is analyzed for fixed and variable torque with speed condition using MATLAB/Simulink software.
\end{abstract}

This is an open access article under the CC BY-SA license.

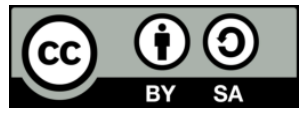

\section{Corresponding Author:}

Ravi Kiran Dasari

Department of Electrical and Electronics Engineering, Sathyabama Institute of Science and Technology

Chennai, India

Email: raviraja.dasari@gmail.com

\section{INTRODUCTION}

Global pollution is a major constraint that is worrying the world these days. Vehicles with internal combustion engines constitute a major source of air pollution emitting particulate matter and carbon gases into the atmosphere. Affordable and clean vehicle technology can improve the quality of air while reducing the climatic changes and health risks. Technology in replacing conventional engines (using fossil fuels) with clean energy engines that exclude tailpipe emissions is the future vehicular scenario. Electric vehicles (EVs) are the one that employs electric motor for its traction and needs no gasoline fuels [1], [2]. The notion of electric vehicle has been for a long period around, but the EV concept gained its interest in the last decade amidst global pollution from the automobile sector. With the development in electrical technology, diversified and sophisticated EVs can be designed with high reliability. Battery driven or renewable source driven EV [3]-[6] can rule the automobile sector in the mere future. Renewable sources like photovoltaic (PV) system [7] or fuel cell can source the electric vehicle. PV energy is freely available and in abundance in a country like India. PV system absorbing photon energy from the sunlight allows current passage generating electrical energy which can be used further. This PV system generating electricity decreases the reliability on conventional sources generating electric power [8]-[10]. Further, the usage of PV energy can be used to drive electric vehicles. Solar radiation which is at peak during day time can generate electrical energy [11] and can be stored in batteries to source the EV.

PV system generates electrical energy at low voltages. The low voltage output of the PV system cannot drive the electric motor of EV and necessitates a voltage boost circuit. The voltage boost circuit gains 
the output of the PV system [12], [13]. Switch-mode DC-DC converters can do a job of voltage gainer. Isolated and non-isolated are the types of DC-DC converters. Isolated converters [14] induct high-frequency transformer for isolation between input and output terminals of the circuit. The use of high-frequency transformer increases the cost and space of the converter. Non-isolated DC-DC converters do not need a transformer [15]-[17] as there is no isolation between input and output terminals of the circuit and requires less output filters as compared to isolated type. DC-DC converters [18]-[20] are also used for charging batteries of electric vehicle [21] and braking [22].

The motor is the heart of the EV circuit. A suitable and efficient motor can run EV [23] and increases system reliability. Machine such as switched reluctance motor (SRM) gained importance in the recent days. Simple construction with robust structure, capability of high speed operations [24] make Switched reluctance motor viable in many applications like electric vehicle [25].

Active switch has voltage stress equal to output voltage in converter [26]. Involving two power devices in current path during switch ON period and one device during switch OFF duration, a transformer less high gain converter is proposed as converter-1 topology in [27]. This paper presents a hybrid boost switch mode DC-DC converter [27] with photovoltaic (PV) system for electric vehicle application. The wheels of the electric vehicle are coupled to switched reluctance motor. Closed-loop speed controlled SRM drives the wheels of EV. Asymmetrical converter feeds the excitation current to the coils of $6 / 4$ pole currentcontrolled SRM. This paper proposes a non-isolating type hybrid DC-DC converter with high voltage conversion ratio to drive SRM machine. Transformer less operation of converter reduces the size and avoids electromagnetic interference/electromagnetic compatibility (EMI/EMC) effects, is an added advantage. The converter is operated in closed-loop and continuous conduction mode (CCM) mode. Two inductors with the same level of inductance are charged in parallel during the switch-on period and are discharged in series during the switch-off period.

Novelty of the work:

- This paper presents a hybrid boost switch mode DC-DC converter [27] with PV system for electric vehicle application.

- PV system is taken as input and switched reluctance motor (SRM) drive is considered as load.

- Closed-loop speed control analysis of SRM drive is presented.

- Asymmetrical converter feeds the excitation current to the coils of 6/4 pole current-controlled SRM.

- The hybrid boost converter is operated in closed-loop and Continuous conduction mode.

\section{HYBRID BOOST CONVERTER}

Coupled inductor based technique gives high voltage gain. With low circuit complexity and to increase the voltage gain, [26] proposes a modified boost topology with switched inductor structure. Three power devices are involved in current path during switch ON period and two devices during switch OFF in [26]. Active switch has voltage stress equal to output voltage in converter [26]. Involving two power devices in current path during switch ON period and one device during switch OFF duration, a transformer less high gain converter is proposed as converter-1 topology in [27] which is hybrid boost converter in this article. The voltage stress across the switch is less than the output voltage and the current stress is about half the value of the converter in [26].

\subsection{Hybrid boost converter representation}

Figure 1 shows the hybrid boost converter and it consists of two switches S1 and S2. Also, it consists of two inductor coils L1 and L2, a diode D and a capacitor C. Resistive load is connected across the load terminals. Both the switches of hybrid boost converter are switched simultaneously with no phase delay. The operational modes of hybrid boost converter, when both the switch units S1 and S2 in ON state is shown in Figure 2 and hybrid boost converter when both the switch units S1 and S2 in OFF state is shown in Figure 3.

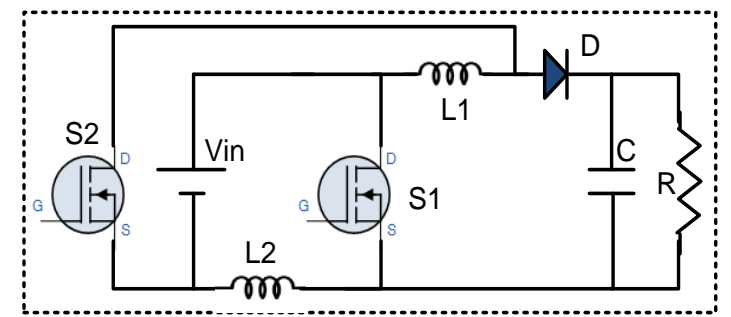

Figure 1. Hybrid boost converter 


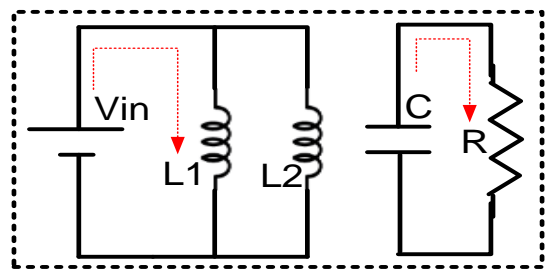

Figure 2. Hybrid boost converter when both S1 \& S2 are ON (Mode-1)

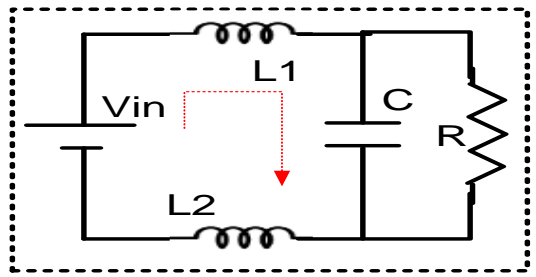

Figure 3. Hybrid boost converter when both S1 \& S2 are OFF (Mode-2)

- Mode-1: When both the switches are ON, the source voltage is present across each inductor and both L1 and L2 are charged up to the voltage level of input source. During this time period, the load is driven by the capacitor.

$$
\operatorname{Vin}=V L 1=V L 2
$$

- Mode-2: If both the switchable units S1 and S2 are turned OFF condition, the input current flows from source through inductor (L1), capacitor (C) and inductor (L2). Since already the inductors are charged up to the level of input value, the capacitor is charged to thrice the value of input source.

Voltage across the inductor (L1=L2) is given (during switch OFF time) by (2).

$$
V_{L}=\left(\frac{V_{\text {in }}-V_{0}}{2}\right)
$$

Figure 4 illustrates the timing and operational signals of hybrid boost converter. The signal character of different parameters during switches ON and switch OFF periods are shown. Making the average voltage across the inductor (with as shown in (1) and (2)), equal to zero over the complete cycle yields the formulation of voltage gain for hybrid boost converter.

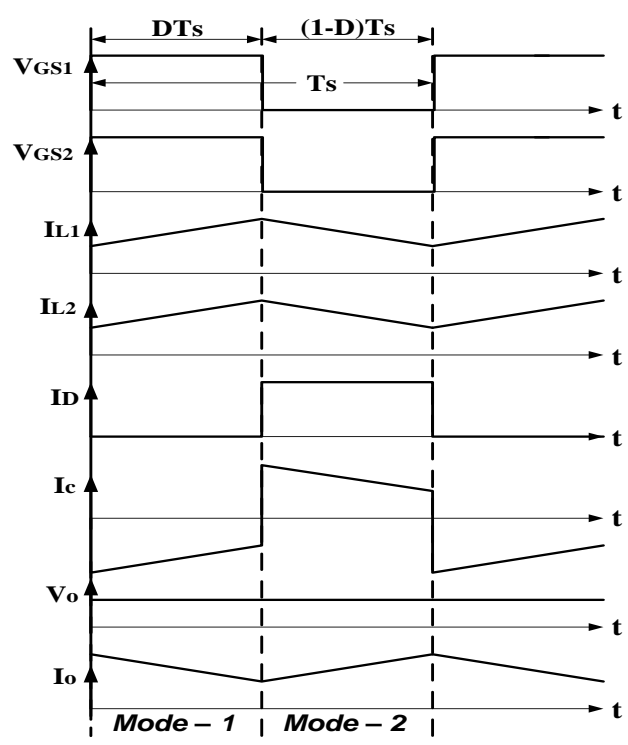

Figure 4. Operational waveforms of hybrid boost converter

$$
\frac{V_{i n} * D T_{S}+\left(\frac{V_{i n}-V_{0}}{2}\right)(1-D) T_{S}}{T_{S}}=0
$$

$$
V_{\text {gain }}=\frac{V_{0}}{V_{\text {in }}}=\frac{1+D}{1-D}
$$


Further, for duty cycle formulation, as shown in (4) can be re-written as:

$$
\begin{aligned}
& (1-D) * V_{0}=(1+D) * V_{i n} \\
& D=\frac{V_{0}-V_{i n}}{V_{0}+V_{i n}}
\end{aligned}
$$

In spite of having one more switch and passive inductor in the hybrid boost (compared to conventional boost circuit) converter, for the said duty cycle, the gain is very high. The duty cycle formulation illustrates that at $50 \%$ duty ratio, the output voltage is thrice the voltage of input value. The duty cycle versus voltage gain comparison is represented in Figure 5, and states that the voltage gain is higher in case of hybrid boost converter. Table 1 shows the comparative illustration of traditional boost converter and hybrid boost converter. Hybrid boost converter boosts the voltage level greater than traditional boost converter.

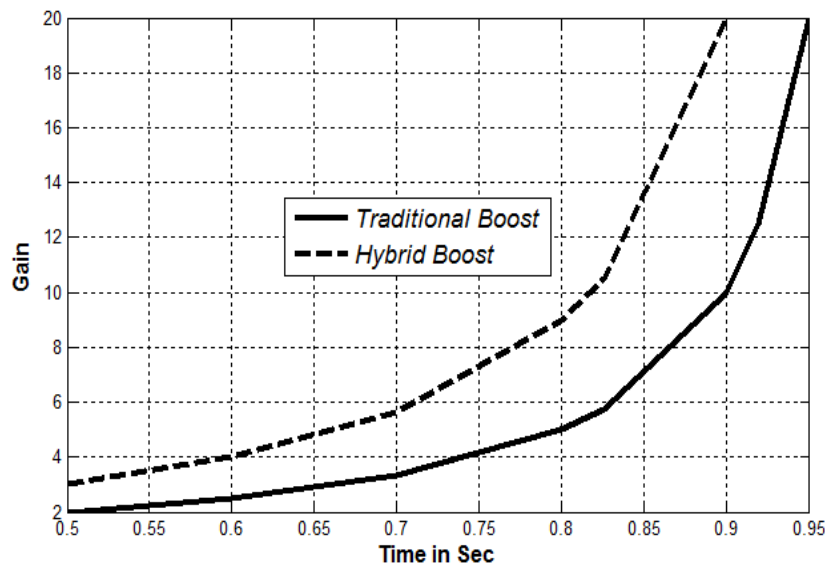

Figure 5. Duty cycle versus voltage gain

Table 1. Comparative chart

\begin{tabular}{lcc}
\hline \multicolumn{1}{c}{ Parameter } & Traditional Boost Converter & Hybrid Boost Converter \\
\hline Value of Inductors & $1 \mathrm{mH}$ & $0.5 \mathrm{mH}$ \\
Size of Inductors & High & Low \\
Number of switches & 01 & 02 \\
Duty Ratio & High & Low \\
Voltage Gain & 1 & $1+D$ \\
& $1-D$ & $1-D$ \\
@ 50\% Duty Cycle & Vout $=2 *$ Vin & Vout $=3 *$ Vin \\
\hline
\end{tabular}

\section{PHOTO-VOLTAIC SYSTEM WITH HYBRID BOOST CONVERTER FED SRM DRIVE}

\subsection{PV system with closed-loop hybrid boost converter}

Solar energy is freely and available in abundant quantity. Use of the solar light for the production of electrical energy is the basic operation of photovoltaic (PV) system. PV cell is a simple fabricated P-N junction layer and when photon energy in the sunlight implicates on silicon layer of PV system, generates electricity. PV cell absorbs the photon energy and the charge carriers inside the P-N layers, gets excited and tries to move from one layer to the other, depleting the junction barrier, allowing the flow of electrons producing electricity.

Multiple modules connected in series (PV string) boosts the voltage level and connected in parallel increases the current rating. Design of PV system is to decide the package number of series and parallel combinations (array) to match up for required power rating. PV system cannot match up for higher voltage ratings due to cost economics and insists for DC-DC converter to boost up the output voltage of PV system. The PV system connected to hybrid boost converter is shown in Figure 6. 


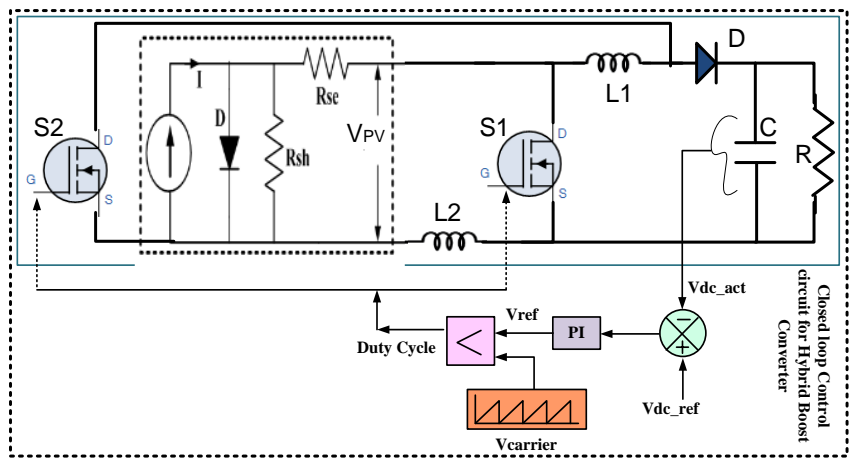

Figure 6. PV with hybrid boost converter

\subsection{Switched reluctance motor with asymmetrical converter}

Switched reluctance motor (SRM) is an electric motor that consists of no windings on rotor while the stator consists of concentrated windings. SRM is known for its double salient construction where both the stator and rotor consists of salient poles. Generally, SRM is heteropolar motor and the number of stator and rotor poles is unequal. SRM operates on the principle of variable reluctance and the rotor rotates with reluctance torque. Stator consists of windings and is excited sequential using a switching converter. The rotor of SRM tends to align itself in low reluctance path. A simple view of three-phase 6/4 pole SRM is shown in Figure 7.

Simple construction with robust structure and especially the capability of high speed operations make Switched reluctance motor (SRM) viable in many applications. High speed machines can produce adequate power density, which is very much an interest in electric vehicle motors. The phases of SRM are independent and the failure in one phase does not interrupt the drive operation. Sequential switching of SRM phase windings produces reluctance path and the winding free rotor aligns in the direction of low reluctance path. The switching of phase windings is done with a switching converter. The windings of SRM are in series with the switches of converter making the limit the shoot-through faults.

The torque of the SRM is self-reliant and does not depend on the polarity of the current excitation, this phenomenon insists for careful handling of stored magnetic energy. The asymmetrical converter to excite and to handle stored magnetic energy in 6/4 pole SRM is shown in Figure 8. Asymmetric converter is one of the common configurations to drive SRM circuit with regeneration and free-wheeling capability. Each phase consists of two switches (T1 and T2 for Phase-A) and two diodes. Turning on both T1 and T2 excites the phase coil and the stored energy of the coil remains in the same direction until it is depleted. Turning off T1 and T2 forward biases the two diodes and the stored energy in the coil is fed back to recharge the source. Turning on T1 and turning off T2 makes diode D2 forward biased and the remaining stored energy in the coil is freewheeled allowing complete discharge of the phase coil. The operating modes of the converter phase are shown in Figure 9. The dark black part of the circuit is the current path and the lighter parts of the circuit are inactive in Figure 9. Each phase consists of two switches (T1 and T2 for Phase-A) and two diodes. Turning on both T1 and T2 in Figure 9 (a) excites the phase coil and the stored energy of the coil remains in the same direction until it is depleted. Turning on T1 and turning off T2 in Figure 9 (b) makes diode D2 forward biased and the remaining stored energy in the coil is freewheeled allowing complete discharge of the phase coil. Turning off T1 and T2 in Figure 9 (c) forward biases the two diodes and the stored energy in the coil is fed back to recharge the source.

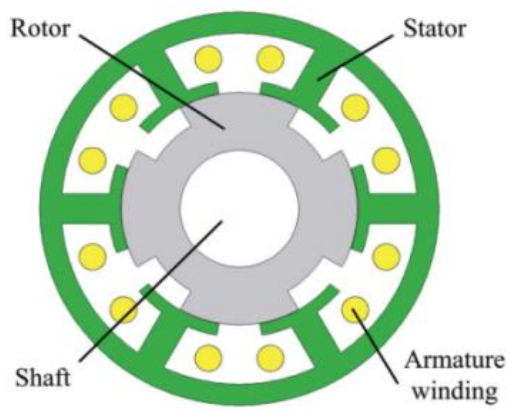

Figure 7. Three-Phase 6/4 SRM

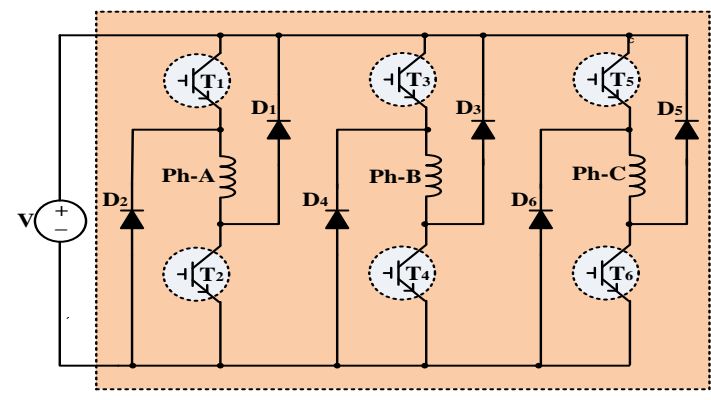

Figure 8. Conventional asymmetrical structure converter for SRM 


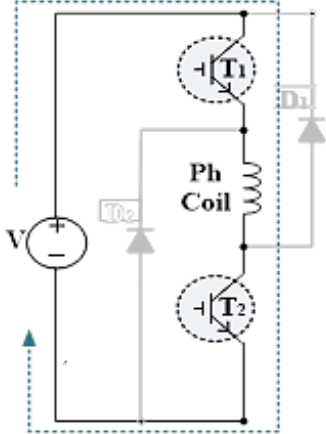

(a)

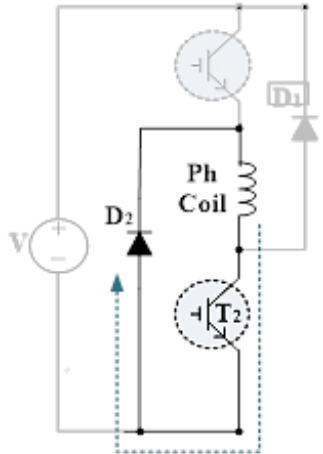

(b)

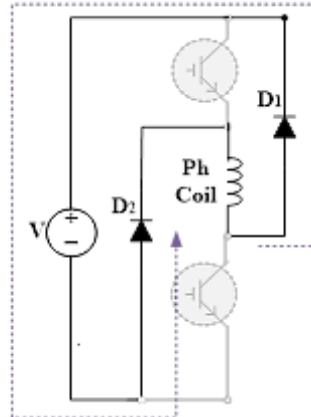

(c)

Figure 9. Operating modes of SRM (a) excitation, (b) free-wheeling, and (c) regeneration

\subsection{PV with hybrid boost converter fed SRM drive for EV application}

Electric vehicle technology is going to trends in the coming days, replacing conventional IC engines, to reduce the vehicular pollution. SRM, being a light machine and capable for high speed operations, is a good choice for electric vehicle applications. Solar system which is freely available can source an electric vehicle. Figure 10 shows the PV with hybrid boost Converter fed SRM Drive for EV application. The PV system output voltage is fed to hybrid boost converter for stepping the PV output. Hybrid boost DC-DC converter is run in closed-loop form to give out desired voltage. The hybrid boost converter output is coupled to asymmetrical converter to sequentially switch the phase windings of switched reluctance motor.

Switched reluctance motor drive is operated in closed-loop mode where the actual motor speed is fed back for correction to run the motor precisely at desired speed. The angular displacement of the rotor is sensed and the current shape is estimated using position sensors. On the other hand, the actual speed of the motor is sensed and is compared with the reference speed. The speed error is corrected using PI controller and generates current magnitude. The earlier generated current shape is multiplied with the current magnitude to generate reference current signal.

The reference current signal is compared with actual stator current signal and the error between reference and the actual current signal through Hysteresis current controller (HCC) generates triggering pulses to the power switches of asymmetrical converter. Sequential switching of SRM windings through asymmetrical converter excites the stator coils and makes rotor to rotate generating torque. The generated torque from SRM is coupled to the electrical vehicle for its wheel rotation.

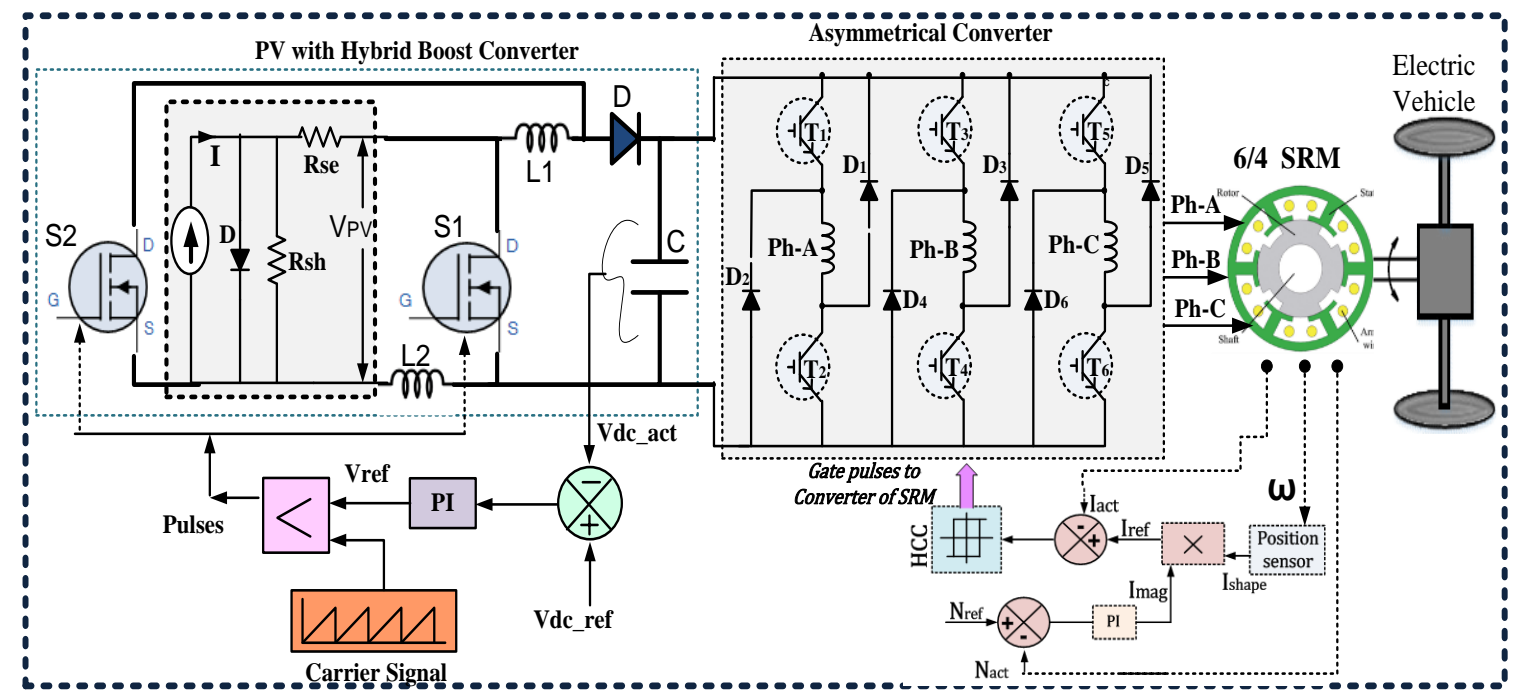

Figure 10. PV system with hybrid boost converter fed SRM drive for EV application 


\section{RESULT ANALYSIS}

Table 2 illustrates the values of different system parameters used in modeling of PV with hybrid boost converter fed SRM drive. The PV system generates $100 \mathrm{~V}$ output voltage to source the system. The PV source signal pattern is fed to hybrid boost DC-DC converter to increase the potential level of PV system.

Table 2. System parameters

\begin{tabular}{lc}
\hline \multicolumn{1}{c}{ Parameter } & Value \\
\hline PV Output & $100 \mathrm{~V}$ \\
Hybrid Boost Converter output & $300 \mathrm{~V}$ \\
Power, P & $10 \mathrm{KW}$ \\
Inductor Current ripple, $\Delta \mathrm{I}_{\mathrm{L}}$ & $5 \mathrm{~A}$ \\
Capacitor Voltage ripple, $\Delta \mathrm{V}_{\mathrm{C}}$ & $6 \mathrm{~V}$ \\
Inductor, L & $0.5 \mathrm{mH}$ \\
Capacitor, C & $138.8 \mu \mathrm{F}$ \\
Stator Resistance of SRM & $0.178 \mathrm{~m} \Omega$ \\
Aligned Inductance & $71.2 \mathrm{mH}$ \\
Unaligned Inductance & $330 \mu \mathrm{H}$ \\
Voltage control & $\mathrm{K}_{\mathrm{P}}=5$ \\
& $\mathrm{~K}_{\mathrm{I}}=1$ \\
Speed control & $\mathrm{K}_{\mathrm{P}}=1$ \\
& $\mathrm{~K}_{\mathrm{I}}=0.1$ \\
\hline
\end{tabular}

\subsection{PV with hybrid boost converter fed SRM drive with fixed torque and fixed speed}

Figure 11 illustrates the PV system output voltage. The PV system generates $100 \mathrm{~V}$ output voltage to source the system. The PV source signal pattern is fed to hybrid boost DC-DC converter to increase the potential level of PV system. Hybrid boost DC-DC converter raises the level of voltage to $300 \mathrm{~V}$ (thrice the input voltage level) as shown in Figure 12.

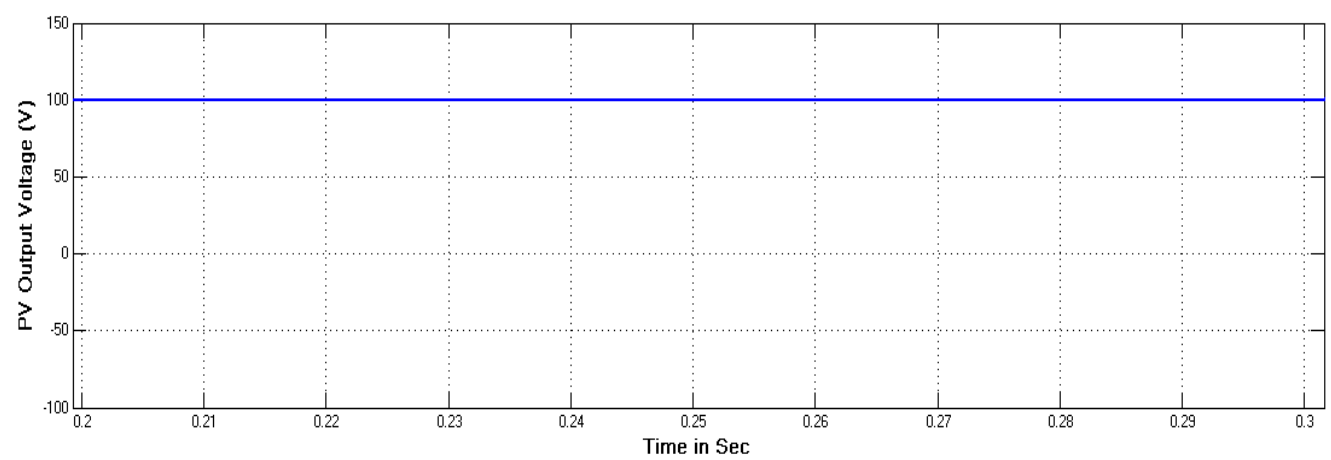

Figure 11. PV output voltage

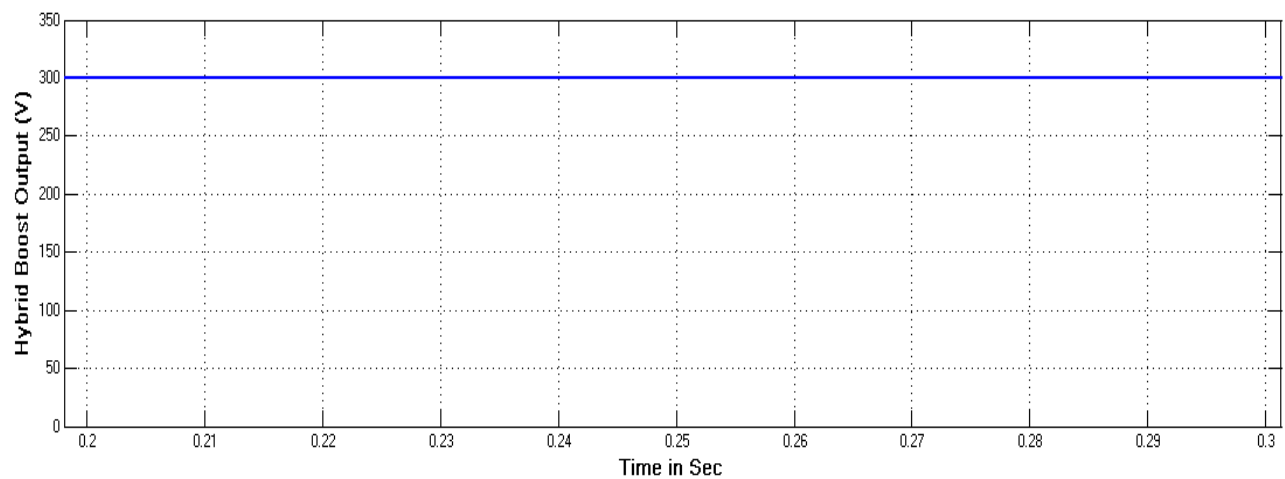

Figure 12. Hybrid boost converter output voltage

Figure 13 shows the ripple current in inductor of hybrid boost converter. The change in inductor current is 5 Amps. Figure 14 shows the capacitor ripple voltage. The change in voltage across capacitor is $6 \mathrm{~V}$. 
Figure 15 shows the stator currents fed to SRM to excite the windings. SRM is excited with peak current of 6 A. Torque generated from SRM drive is shown in Figures 16 and 17 illustrates the speed at which SRM rotates. SRM drive rotates with constant sped of 2000 RPM with constant torque applied.

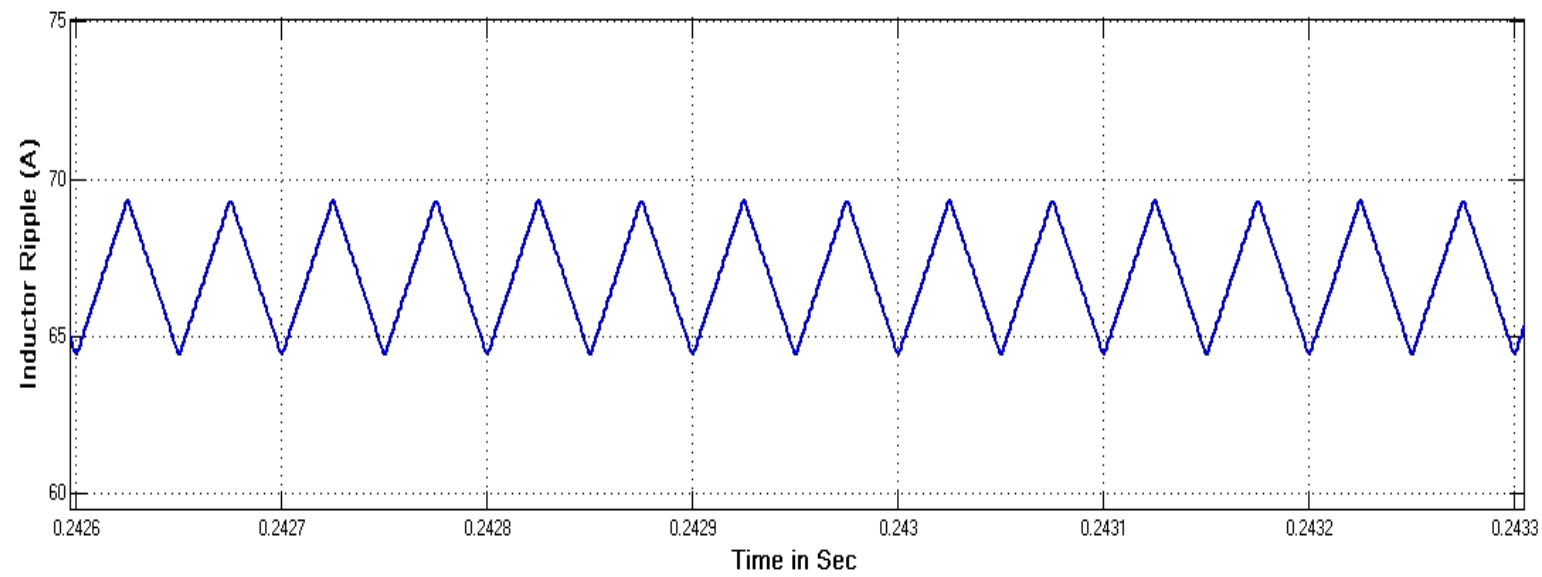

Figure 13. Inductor ripple current

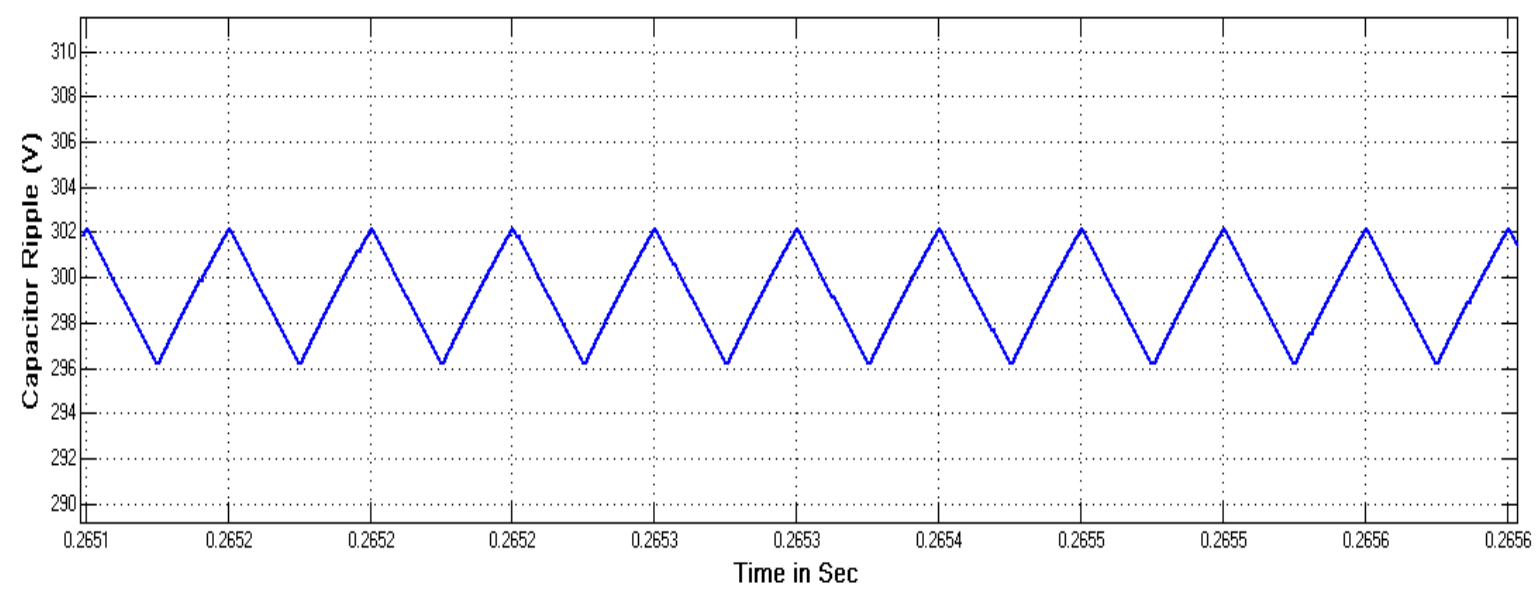

Figure 14. Capacitor ripple voltage

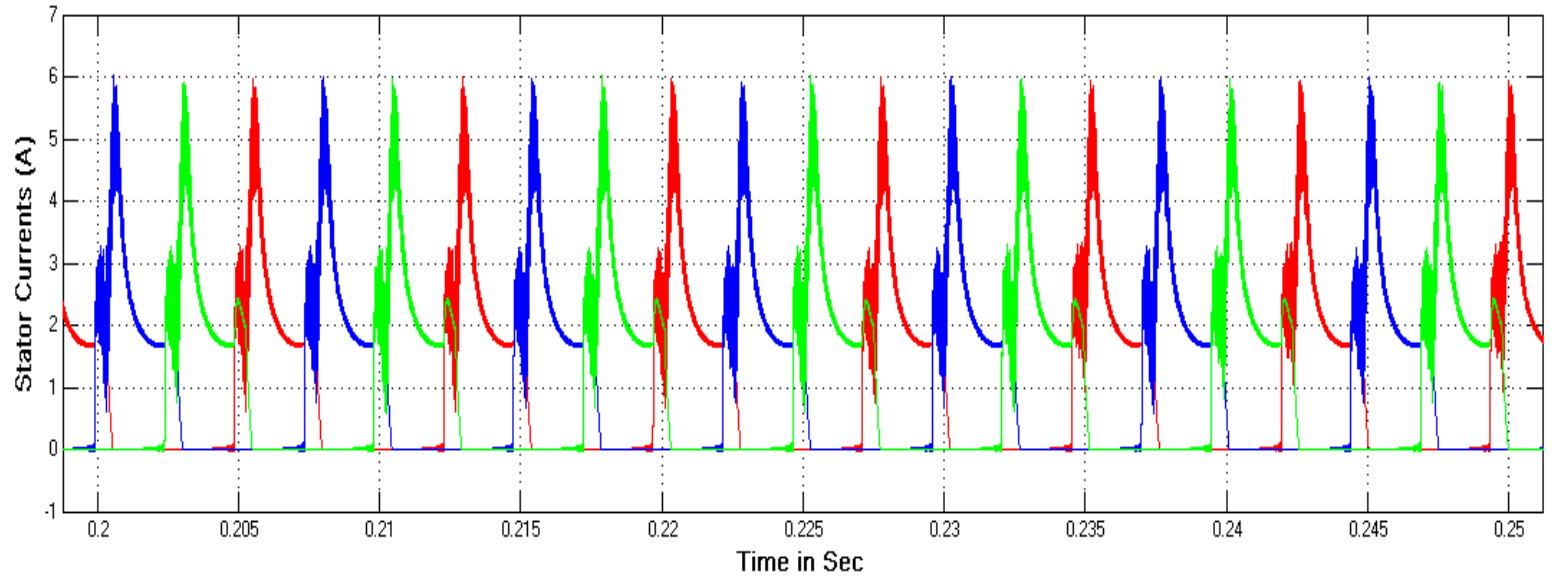

Figure 15. Stator currents 


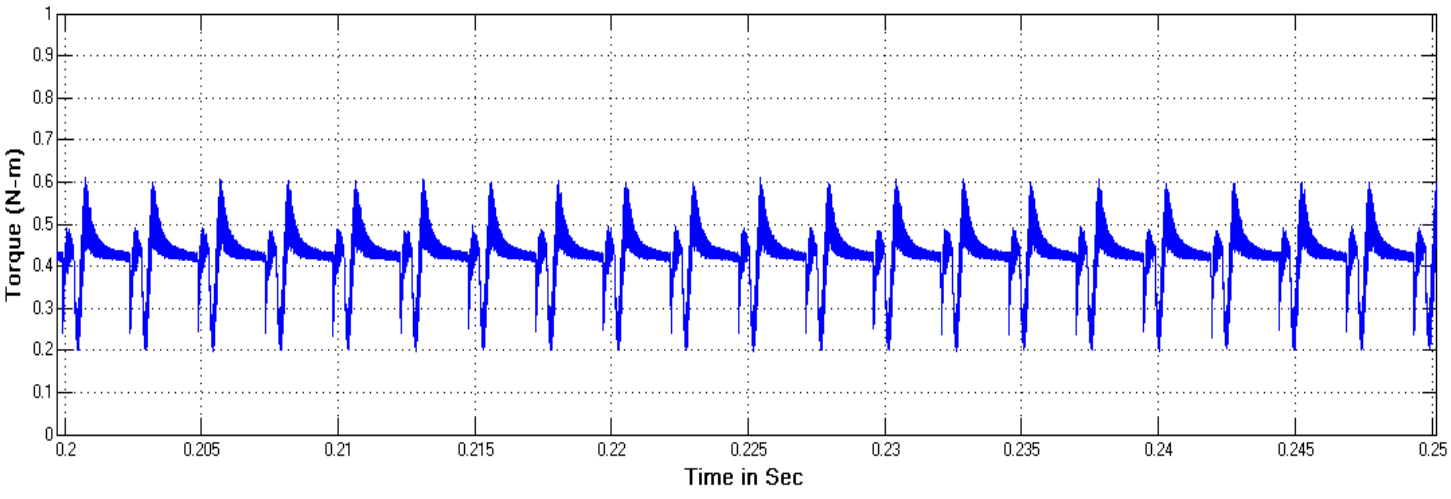

Figure 16. Torque of SRM

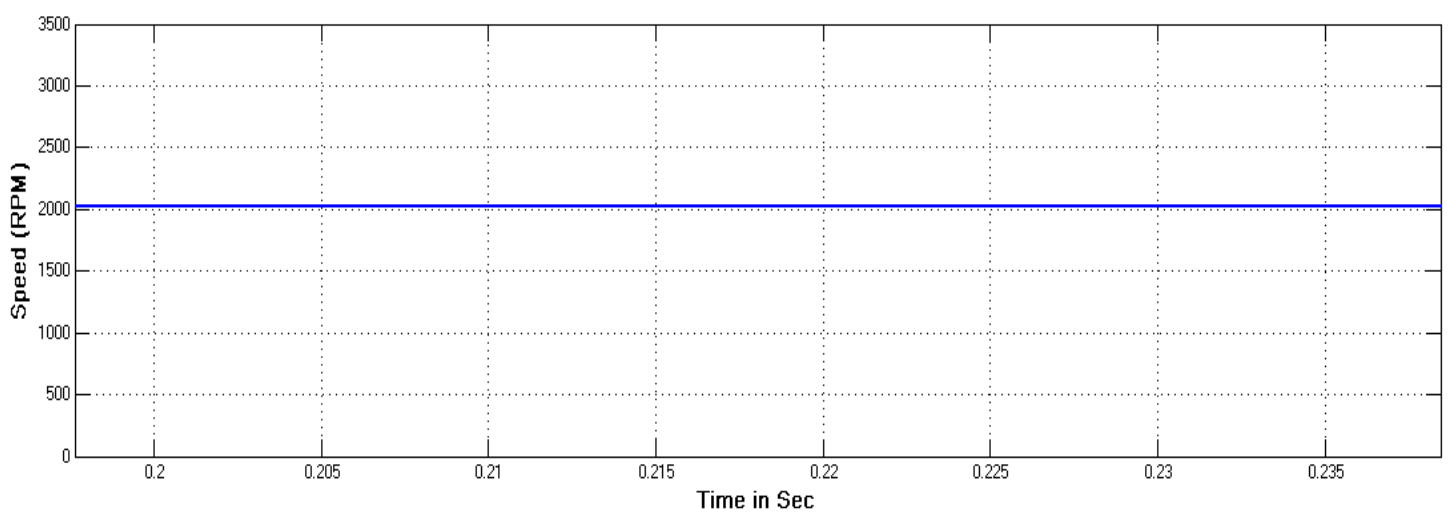

Figure 17. Speed of SRM

\subsection{PV with hybrid boost converter fed SRM drive with variable torque and fixed speed}

Figure 18 illustrates the PV system output voltage. The PV system generates $100 \mathrm{~V}$ output voltage to source the system. The PV source signal pattern is fed to hybrid boost DC-DC converter to increase the potential level of PV system. Hybrid boost DC-DC converter raises the level of voltage to $300 \mathrm{~V}$ (thrice the input voltage level) as shown in Figure 19. Figure 20 shows the hybrid boost converter inductor ripple current. The change in inductor current is 5 Amps. Figure 21 shows the capacitor ripple voltage. The change in voltage across capacitor is $6 \mathrm{~V}$.

Figure 22 shows the three-phase stator currents fed to SRM to excite the windings. SRM is excited with peak current of 10A. Torque generated from SRM drive and the speed at which SRM rotates is shown in Figure 22. SRM drive rotates at constant speed of 2000 RPM before and after torque change applied at 0.25 sec. The change in torque is clearly indicated at $0.25 \mathrm{sec}$.

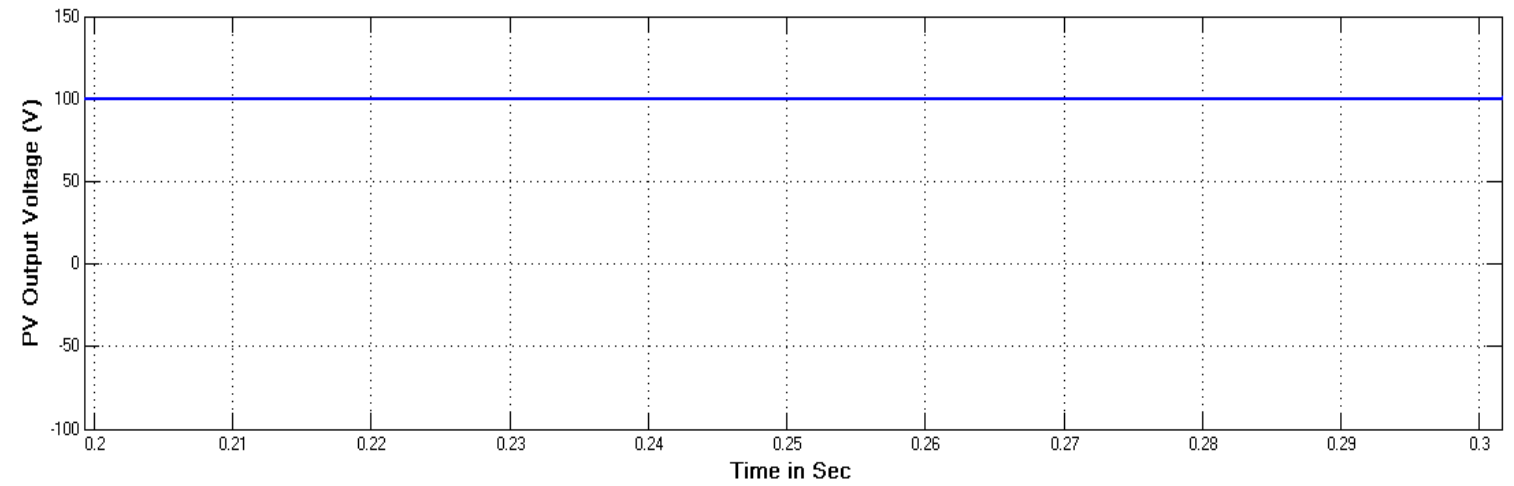

Figure 18. PV output voltage 


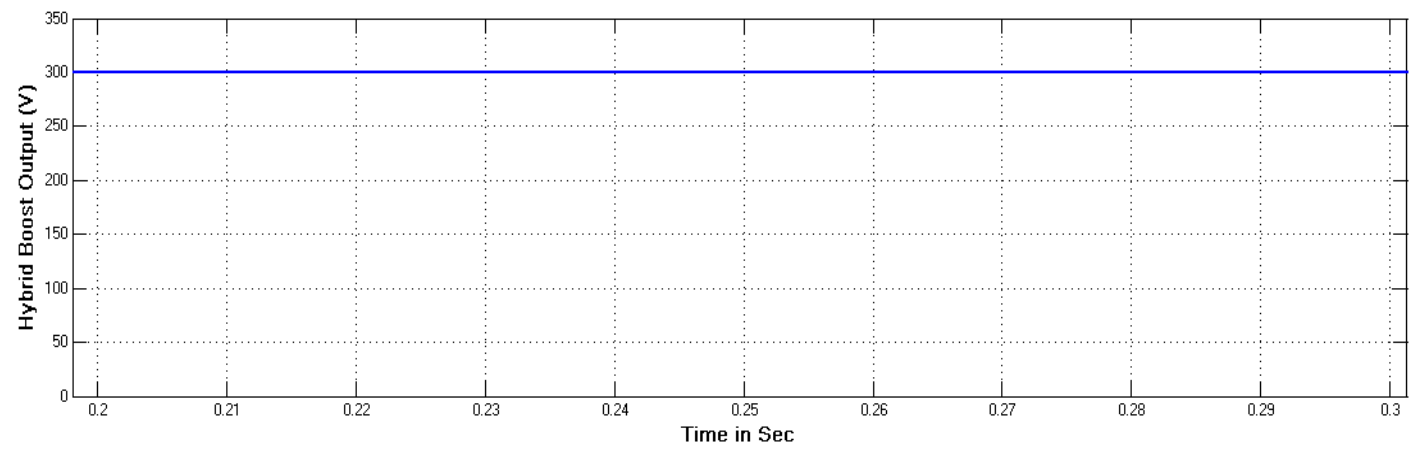

Figure 19. Hybrid boost converter output voltage

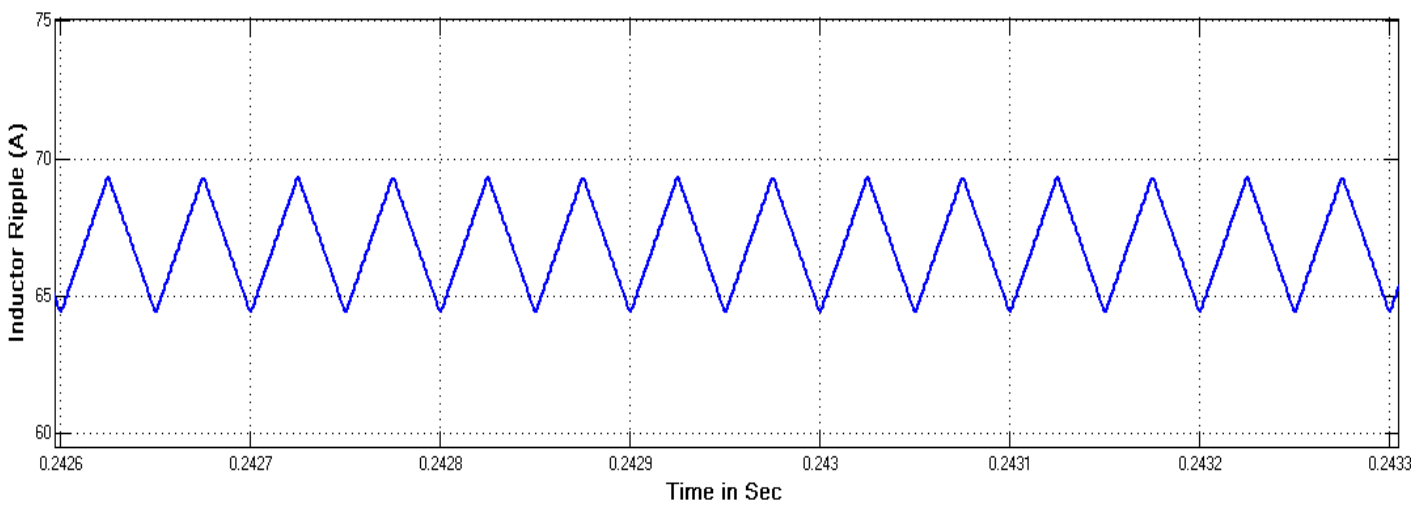

Figure 20. Inductor ripple current

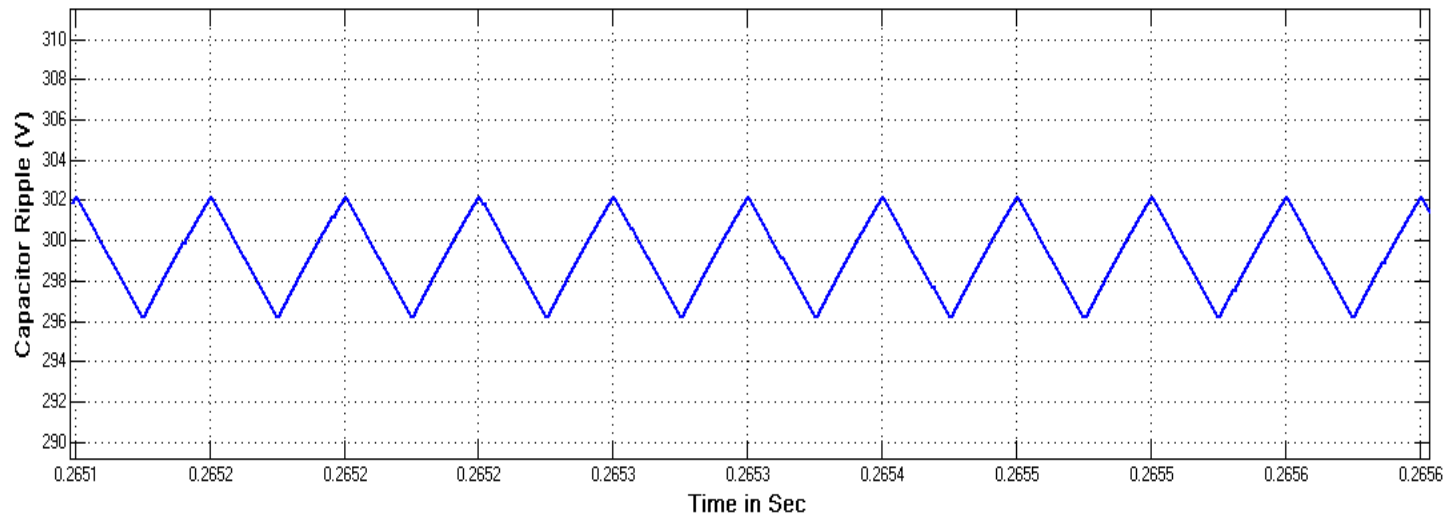

Figure 21. Capacitor ripple voltage

\subsection{PV with hybrid boost converter fed SRM drive with fixed torque and variable speed}

Figure 23 illustrates the PV system output voltage. The PV system generates $100 \mathrm{~V}$ output voltage to source the system. The PV source signal pattern is fed to hybrid boost DC-DC converter to increase the potential level of PV system. Hybrid boost DC-DC converter raises the level of voltage to $300 \mathrm{~V}$ (thrice the input voltage level) as shown in Figure 24. Figure 25 shows the ripple current in inductor of hybrid boost converter. The change in inductor current is 8 Amps. Figure 26 shows the capacitor ripple voltage. The change in voltage across capacitor is $5 \mathrm{~V}$.

Figure 27 shows the stator currents fed to SRM to excite the windings. SRM is excited with peak current of 6 A. Torque generated from SRM drive is shown in Figures 28 and 29 illustrates the speed at which SRM rotates. SRM drive initially rotates with constant sped of 2000 RPM with constant torque applied. At $0.3 \mathrm{sec}$, speed change command is given to run the motor at $3000 \mathrm{RPM}$. The control circuitry acts according to the reference signal and makes motor to run at desired speed aligning the reference speed 


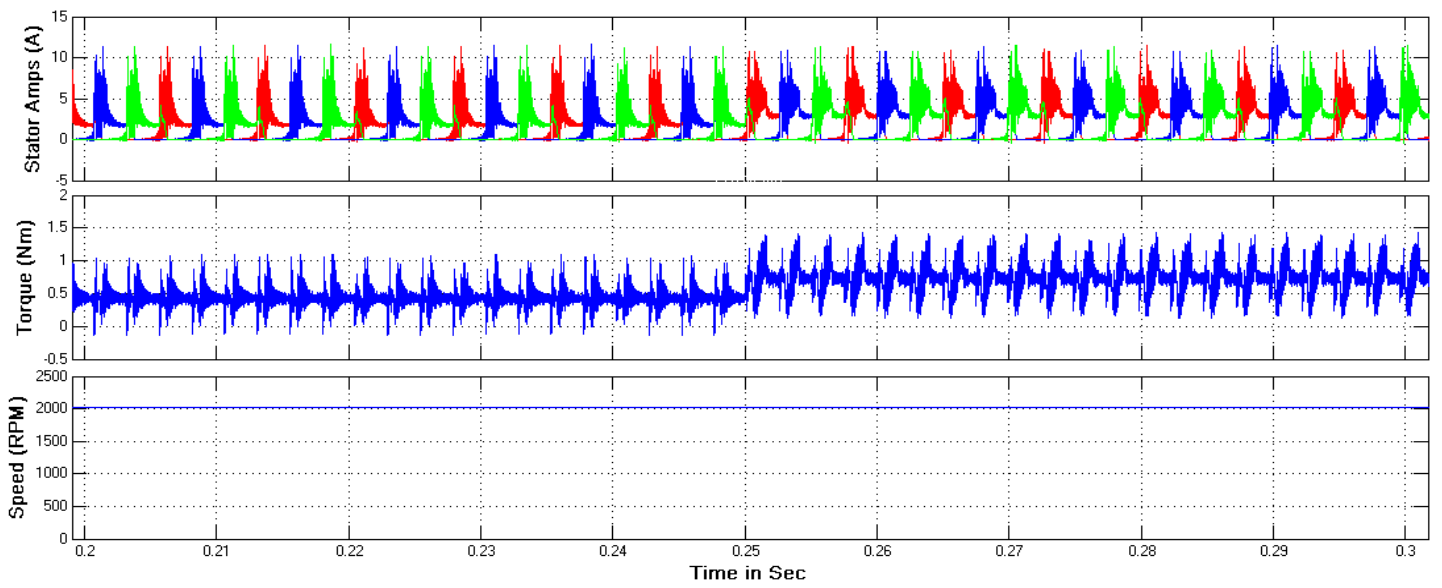

Figure 22. Stator currents, torque and speed of SRM drive

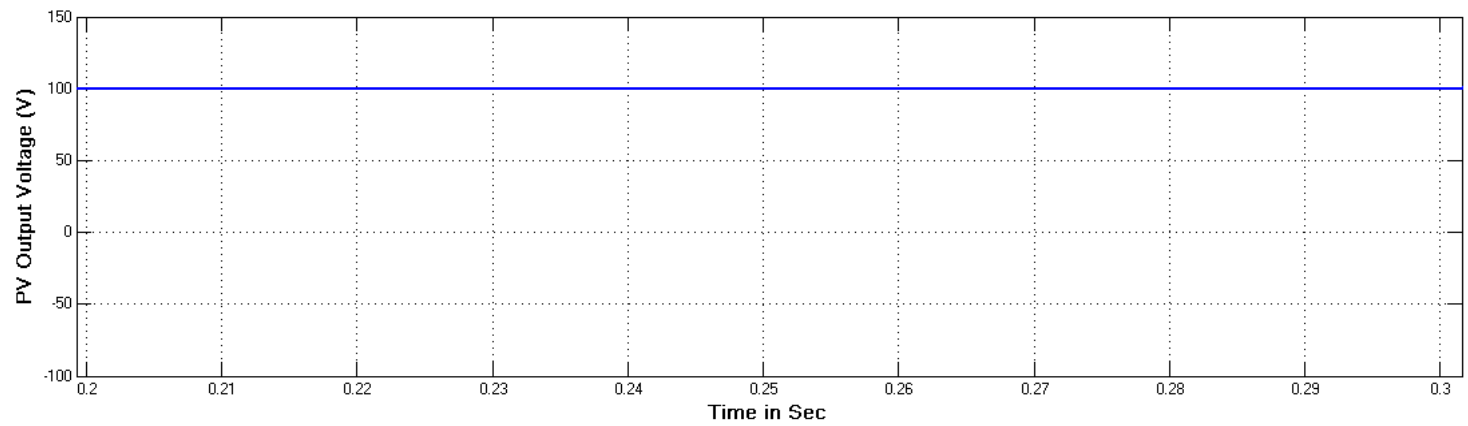

Figure 23. PV output voltage

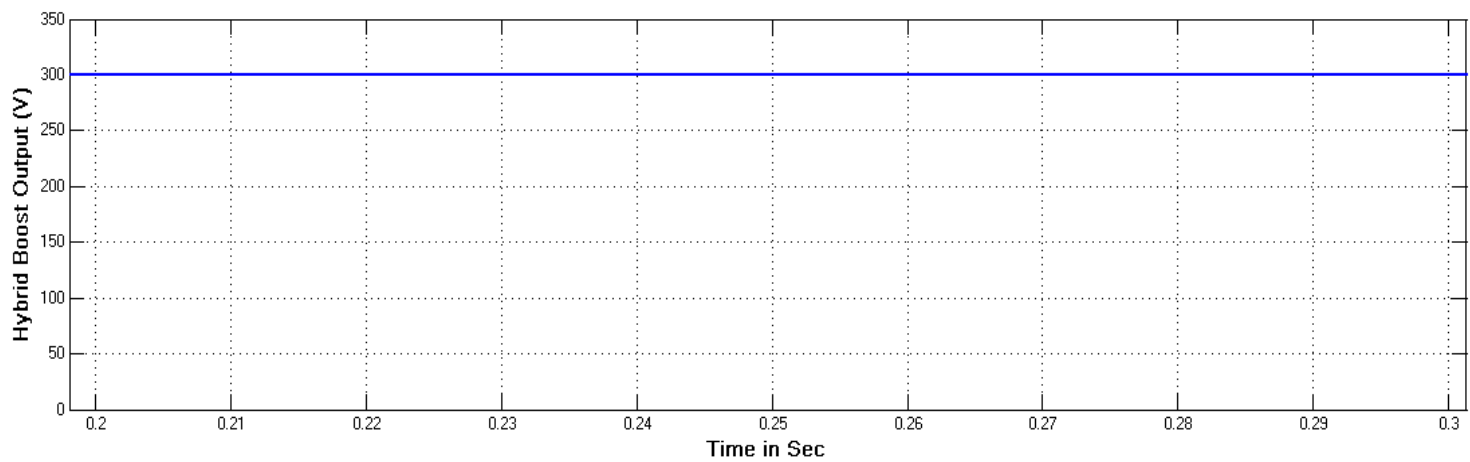

Figure 24. Hybrid boost converter output voltage

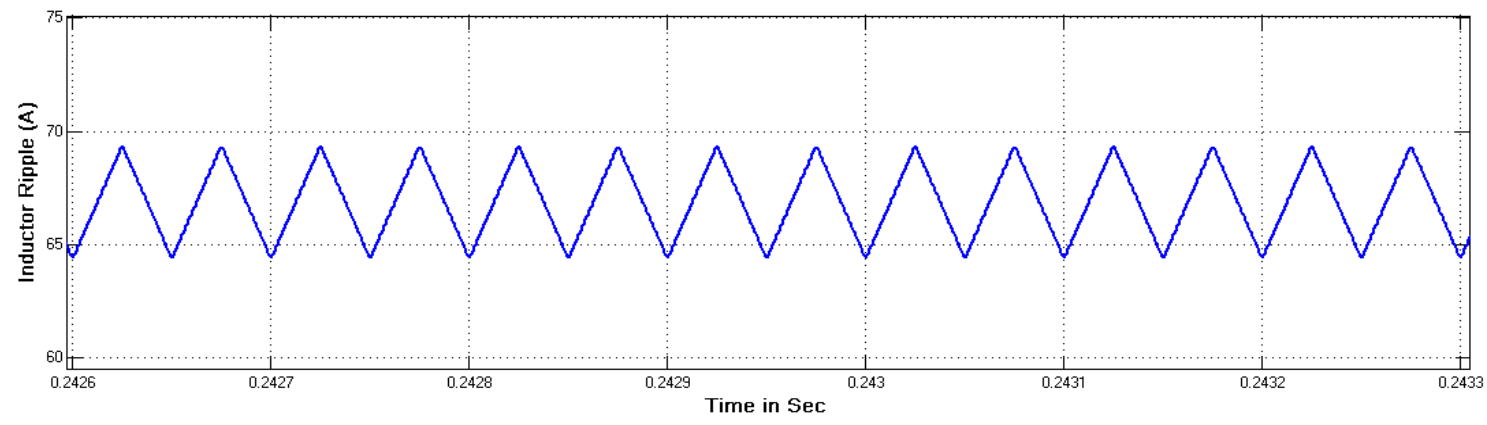

Figure 25. Inductor ripple current 


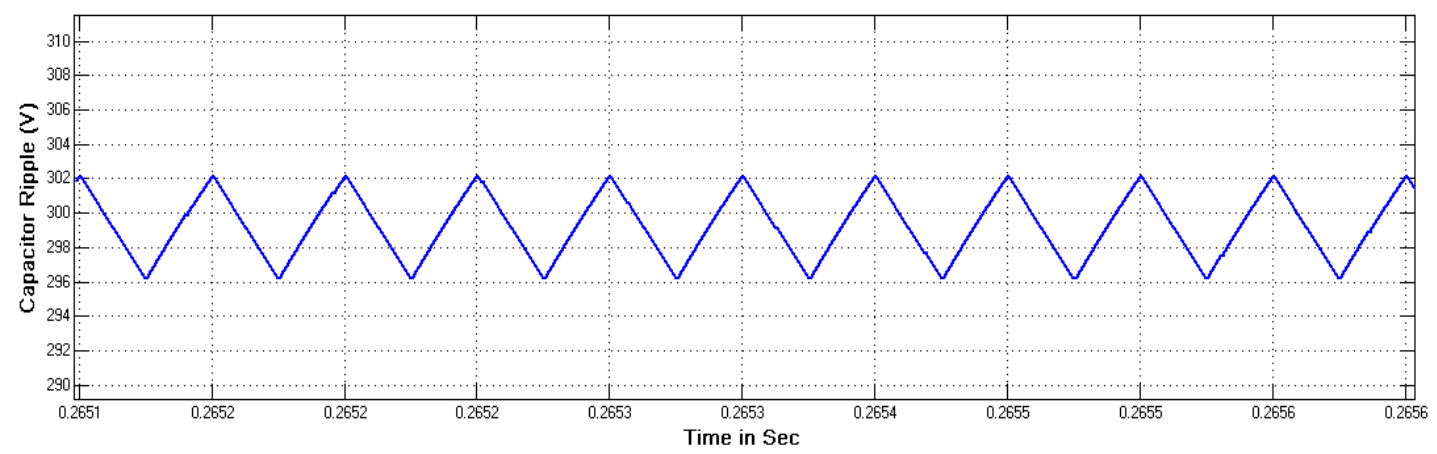

Figure 26. Capacitor ripple voltage

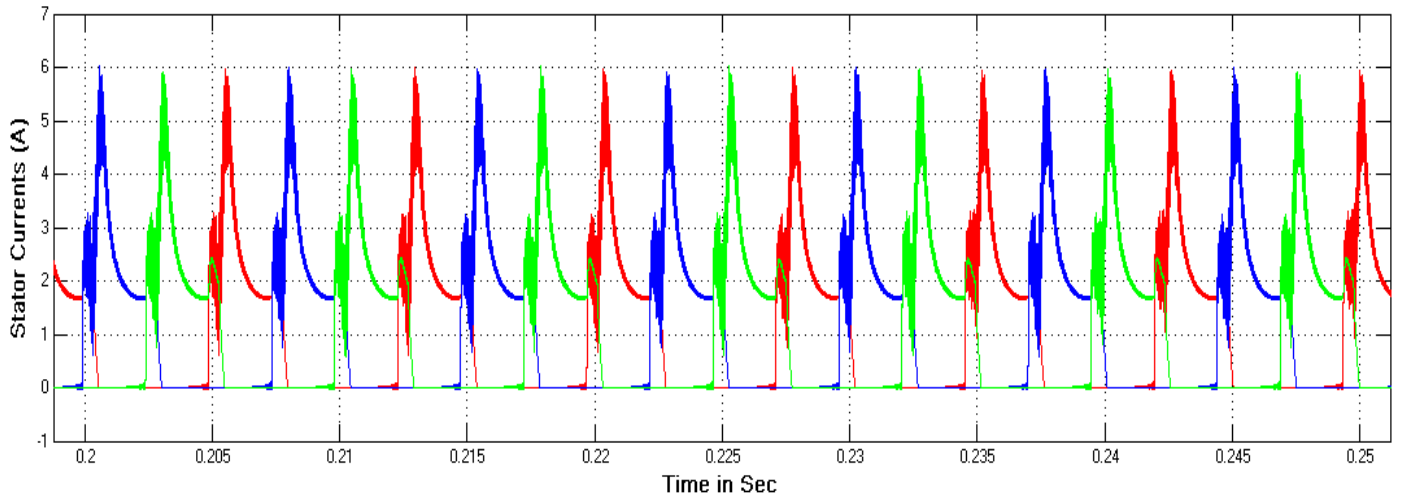

Figure 27. Stator currents of SRM

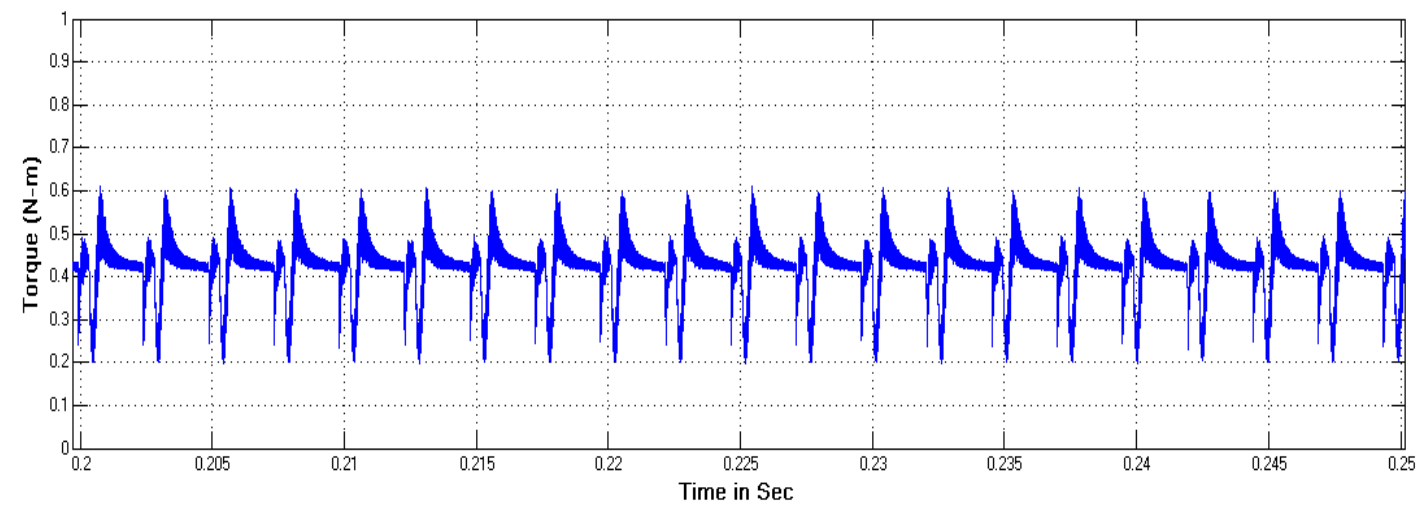

Figure 28. Torque of SRM

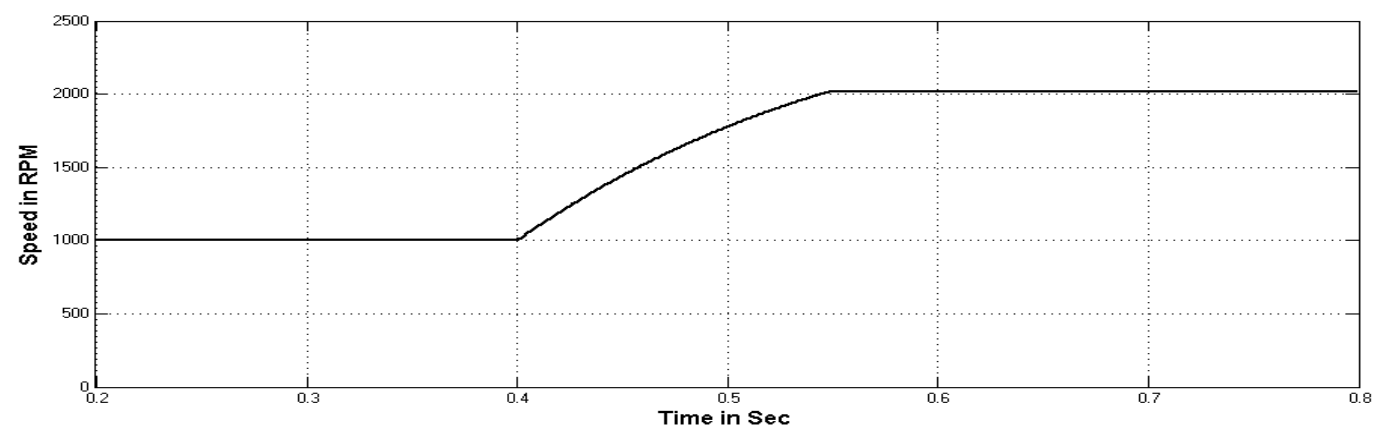

Figure 29. Speed of SRM 


\section{CONCLUSION}

Traditional Internal Combustion engine based vehicular transportation emits lot of pollution which causes global warming. Electric vehicles emit zero pollution and with the more electric vehicles on road are viable to give environment friendly transportation. The paper presents a PV system with hybrid boost DC-DC converter fed SRM drive for EV application. Involving two power devices in current path during switch ON period and one device during switch OFF duration, a transformer less hybrid boost converter presented in this article has voltage stress across the switch less than the output voltage. Hybrid boost converter with PV system as input is operated in closed loop mode to drive SRM. Design of hybrid boost converter is illustrated. Asymmetrical converter feeds the excitation current to the coils of $6 / 4$ pole current-controlled SRM. Speed control of SRM is illustrated in closed loop mode and yields optimal speed operation. Result analysis is provided with different cases like-SRM with fixed speed and torque, variable torque with fixed speed, variable speed with fixed torque conditions. In all the cases the optimal torque and speed control is achieved and illustrates the analysis is suitable for different running conditions. Further, a novel converter with high gain (with switched inductor topology) can be developed with similar analysis for solar power electric vehicles. MPPT system can be incorporated to Solar system to extract maximum power from the solar module. Analysis with different MPPT techniques using advanced AI or genetic algorithms can be done and an optimal or novel MPPT technique can be suggested.

\section{REFERENCES}

[1] C. Liu, K. T. Chau, D. Wu, and S. Gao, "Opportunities and Challenges of Vehicle-to-Home, Vehicle-to-Vehicle, and Vehicle-toGrid Technologies," Proceedings of the IEEE, vol. 101, no. 11, pp. 2409-2427, Nov. 2013, doi: 10.1109/JPROC.2013.2271951.

[2] A. M.Andwari, A. Pesiridis, S. Rajoo, R. M.-Botas, and V. Esfahanian, "A review of Battery Electric Vehicle technology and readiness levels,"Renewable and Sustainable Energy Reviews, vol. 78, pp. 414-430, 2017, doi: 10.1016/j.rser.2017.03.138

[3] C. Jin, X. Sheng, and P. Ghosh, "Optimized Electric Vehicle Charging with Intermittent Renewable Energy Sources," IEEE Journal of Selected Topics in Signal Processing, vol. 8, no. 6, pp. 1063-1072, Dec. 2014, doi: 10.1109/JSTSP.2014.2336624.

[4] C. Luo, Y. Huang, and V. Gupta, "Stochastic Dynamic Pricing for EV Charging Stations with Renewable Integration and Energy Storage," IEEE Transactions on Smart Grid, vol. 9, no. 2, pp. 1494-1505, March 2018, doi: 10.1109/TSG.2017.2696493.

[5] A. Y. Saber and G. K. Venayagamoorthy, "Plug-in Vehicles and Renewable Energy Sources for Cost and Emission Reductions," IEEE Transactions on Industrial Electronics, vol. 58, no. 4, pp. 1229-1238, April 2011, doi: 10.1109/TIE.2010.2047828.

[6] W. A. Salah, M. A. M. Albreem, B. Alsayid, and B. A. Zneid, "Electric vehicle technology impacts on energy," International Journal of Power Electronics and Drive System (IJPEDS), vol. 10, no. 1, pp. 1-9, Mar. 2019, doi: 10.11591/ijpeds.v10.i1.pp1-9.

[7] A. R. Bhatti, Z. Salam, M. J. B. A. Aziz, and K. P. Yee, "A comprehensive overview of electric vehicle charging using renewable energy," International Journal of Power Electronics and Drive Systems (IJPEDS), vol. 7, no. 1, pp. 114-123, 2016, doi: 10.11591/ijpeds.v7.i1.pp114-123.

[8] J. Y. Yong, V. K. Ramachandaramurthy, K. M. Tan, and N. Mithulananthan, "A review on the state-of-the-art technologies of electric vehicle, its impacts and prospects," Renewable and Sustainable Energy Reviews, vol. 49, pp. 365-385, 2015, doi: 10.1016/j.rser.2015.04.130.

[9] E. Du et al., "The Role of Concentrating Solar Power Toward High Renewable Energy Penetrated Power Systems," IEEE Transactions on Power Systems, vol. 33, no. 6, pp. 6630-6641, Nov. 2018, doi: 10.1109/TPWRS.2018.2834461.

[10] A. Subramanian and Santha KR, "Review of multiport isolated bidirectional converter interfacing renewable and energy storage systems," International Journal of Power Electronics and Drive System (IJPEDS), vol. 11, no. 1, pp. 466-476, Mar. 2020, doi: 10.11591/ijpeds.v11.i1.pp466-467.

[11] V. Telukunta, J. Pradhan, A. Agrawal, M. Singh, and S. G. Srivani, "Protection challenges under bulk penetration of renewable energy resources in power systems: A review," CSEE Journal of Power and Energy Systems, vol. 3, no. 4, pp. 365-379, Dec. 2017, doi: 10.17775/CSEEJPES.2017.00030.

[12] V. Lojpur and I. L. J. Validžić, "Influence of Different Light Sources, Light Intensities, and Water Flow Lens (WFL) System on Dye-Sensitized Solar Cell Performances," IEEE Journal of Photovoltaics, vol. 9, no. 2, pp. 492-498, March 2019, doi: 10.1109/JPHOTOV.2018.2887040.

[13] V. Karthikeyan, S. Kumaravel, and G. Gurukumar, "High Step-Up Gain DC-DC Converter with Switched Capacitor and Regenerative Boost Configuration for Solar PV Applications," IEEE Transactions on Circuits and Systems II: Express Briefs, vol. 66, no. 12, pp. 2022-2026, Dec. 2019, doi: 10.1109/TCSII.2019.2892144.

[14] T. Cheng, D. D. -C. Lu, and L. Qin, "Non-Isolated Single-Inductor DC/DC Converter with Fully Reconfigurable Structure for Renewable Energy Applications," IEEE Transactions on Circuits and Systems II: Express Briefs, vol. 65, no. 3, pp. 351-355, March 2018, doi: 10.1109/TCSII.2017.2712286.

[15] K. Tseng, J. Lin, and C. Huang, "High Step-Up Converter with Three-Winding Coupled Inductor for Fuel Cell Energy Source Applications," IEEE Transactions on Power Electronics, vol. 30, no. 2, pp. 574-581, Feb. 2015, doi: 10.1109/TPEL.2014.2309793.

[16] A. Ajami, H. Ardi, and A. Farakhor, "A Novel High Step-up DC/DC Converter Based on Integrating Coupled Inductor and Switched-Capacitor Techniques for Renewable Energy Applications,” IEEE Transactions on Power Electronics, vol. 30, no. 8, pp. 4255-4263, Aug. 2015, doi: 10.1109/TPEL.2014.2360495.

[17] H. Ardi, A. Ajami, and M. Sabahi, "A Novel High Step-Up DC-DC Converter with Continuous Input Current Integrating Coupled Inductor for Renewable Energy Applications," IEEE Transactions on Industrial Electronics, vol. 65, no. 2, pp. 13061315, Feb. 2018, doi: 10.1109/TIE.2017.2733476.

[18] N. Zhang, D. Sutanto, and K. M. Muttaqi, "A review of topologies of three-port dc-dc converters for the integration of renewable energy and energy storage system," Renewable and Sustainable Energy Reviews, vol. 56, pp. 388-401, 2016, doi: 10.1016/j.rser.2015.11.079. 
[19] J. Zhang, H. Wu, X. Qin, and Y. Xing, "PWM Plus Secondary-Side Phase-Shift Controlled Soft-Switching Full-Bridge ThreePort Converter for Renewable Power Systems," IEEE Transactions on Industrial Electronics, vol. 62, no. 11, pp. 7061-7072, Nov. 2015, doi: 10.1109/TIE.2015.2448696.

[20] H. Wu, J. Zhang, X. Qin, T. Mu, and Y. Xing, "Secondary-Side-Regulated Soft-Switching Full-Bridge Three-Port Converter Based on Bridgeless Boost Rectifier and Bidirectional Converter for Multiple Energy Interface," IEEE Transactions on Power Electronics, vol. 31, no. 7, pp. 4847-4860, Jul. 2016, doi: 10.1109/TPEL.2015.2473002.

[21] A. D. Savio and V. Juliet A, "Development of multiple plug-in electric vehicle mobile charging station using bidirectional converter," International Journal of Power Electronics and Drive System (IJPEDS), vol. 11, no. 2, pp. 785 791, Jun. 2020, doi: 10.1109/TPEL.2015.2473002.

[22] M. Kavitha, V. Elanangai, S. Jayaprakash, and V. Balasubramanian, "Development of regenerative braking concept for electric vehicle enhanced with bidirectional converter," International Journal of Power Electronics and Drives (IJPEDS), vol. 9, no. 4, pp. 1584-1590, 2018, doi: 10.11591/ijpeds.v9.i4.pp1584-1590.

[23] K. Rajashekara, "Present Status and Future Trends in Electric Vehicle Propulsion Technologies," IEEE Journal of Emerging and Selected Topics in Power Electronics, vol. 1, no. 1, pp. 3-10, March 2013, doi: 10.1109/JESTPE.2013.2259614.

[24] J. Zhu, K. W. E. Cheng, X. Xue, and Y. Zou, "Design of a New Enhanced Torque In-Wheel Switched Reluctance Motor with Divided Teeth for Electric Vehicles," IEEE Transactions on Magnetics, vol. 53, no. 11, pp. 1-4, Nov. 2017, Art no. 2501504, doi: 10.1109/TMAG.2017.2703849.

[25] J. Fan et al., "Thermal Analysis of Permanent Magnet Motor for the Electric Vehicle Application Considering Driving Duty Cycle,"IEEE Transactions on Magnetics, vol. 46, no. 6, pp. 2493-2496, June 2010, doi: 10.1109/TMAG.2010.2042043.

[26] B. Axelrod, Y. Berkovich, and A. Ioinovici, "Switched-Capacitor/Switched-Inductor Structures for Getting Transformerless Hybrid DC-DC PWM Converters," IEEE Transactions on Circuits and Systems I: Regular Papers, vol. 55, no. 2, pp. 687-696, March 2008, doi: 10.1109/TCSI.2008.916403.

[27] L. Yang, T. Liang, and J. Chen, “Transformerless DC-DC Converters with High Step-Up Voltage Gain,” IEEE Transactions on Industrial Electronics, vol. 56, no. 8, pp. 3144-3152, Aug. 2009, doi: 10.1109/TIE.2009.2022512.

\section{BIOGRAPHIES OF AUTHORS}

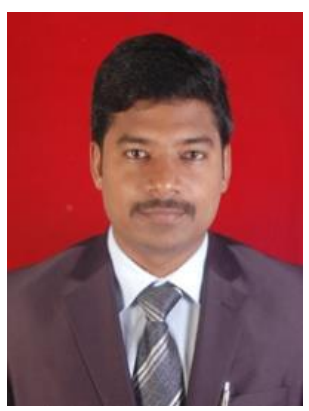

Ravi Kiran Dasari (D) SIS SC P obtained his bachelor's degree in Electrical and Electronics Engineering from JNTUK University, Andhra Pradesh, India, in 2009 and master's degree in Power Electronics and Drives from JNTUK University, Andhra Pradesh, India, in 2013. Currently he is pursuing his $\mathrm{PhD}$ from Sathyabama Institute of Science \& Technology, deemed to be University, Chennai. He is also working as an Assistant Professor in the Department of Electrical \& Electronics Engineering, Andhra Loyola Institute of Engineering \& Technology, Vijayawada. His research interests include Electric Vehicles, Power Electronics converters, renewable energy conversions, Special Machine Drives and power quality control. He can be contacted at email: raviraja.dasari@gmail.com.

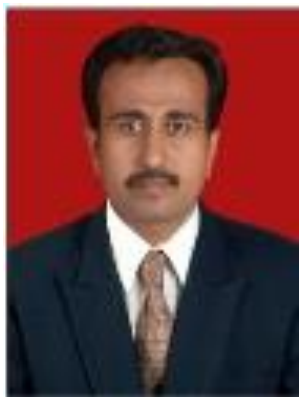

Dharmaraj Godwin Immanuel (D) 81 SC P obtained B.E degree in Electrical and Electronics Engineering from Manonmaniam Sundarnar University, Tirunelveli in the year 2002. He later completed his Masters in Power System Engineering from Annamalai University, Chidambaram in the year 2004 and completed his Phd from Sathyabama University, Chennai in the year 2015. He has published more than 40 papers in various Journals and Conferences. $\mathrm{He}$ is currently working as an Associate Professor in Sathyabama Institute of Science and Technology Chennai, India. His research interest includes Wind energy conversion system, Power Electronic Converters, Smart grid, FACTS and Power System optimization problems. He can be contacted at email: dgodwinimmanuel@gmail.com. 